\title{
Plant Population Structure and Insect Herbivory on Solanum mauritianum Scopoli (Solanaceae) in Southern Brazil: a Support to Biological Control
}

\author{
Deise Mari Barboza, Márcia Cristina Mendes Marques $^{1}$, José Henrique Pedrosa-Macedo ${ }^{2 *}$ \\ and Terence Olckers ${ }^{3}$ \\ ${ }^{1}$ Laboratório de Ecologia Vegetal; Departamento de Botânica; Setor de Ciências Biológicas; Universidade Federal \\ do Paraná; C.P.: 19031; 81531-980; Curitiba - PR - Brasil. ${ }^{2}$ Laboratório Neotropical de Controle Biológico de \\ Plantas; Setor de Ciências Agrárias; Rua Bom Jesus, 650; 80035-010; Curitiba - PR - Brasil. ${ }^{3}$ School of Biological \\ and Conservation Sciences; University of Kwa Zulu-Nata; Private Bag X0; Scottsville 3209; Piet ermaritzburg - \\ South Africa
}

\begin{abstract}
Solanum mauritianum Scopoli (Solanaceae), a native Brazilian shrub, has become naturalized and invasive in several countries. In South Africa, where invasions are severe, herbivorous insects that attack S. mauritianum in its native area have been considered for introduction as biological control agents. To assess the action of such herbivores on the plant, studies were carried out on a population of S. mauritianum in an area undergoing regeneration in southern Brazil. An analysis of the structure of that population was performed, as well as of herbivory by insects, in particular of Anthonomus (Curculionidae). The population structure showed an "inverted $J$ " pattern in diameter classes, but not in height classes. Individual plants showed an aggregate distribution. The damage caused by Anthonomus did not amount to the loss of a large leaf area, but since it was inflicted on young leaves and in a large proportion, could lead to the survival decrease.
\end{abstract}

Key words: Population structure, Solanum, Anthonomus, Herbivory, Biological control

\section{INTRODUCTION}

Solanum mauritianum Scopoli (Solanaceae), commonly known as "cuvitinga" or "fumo-bravo" (Kissman and Groth, 1995), is a native plant from southern Brazil that has become naturalized in Africa, Australasia, India and islands of the Atlantic, Indian and Pacific Oceans, probably through the Portuguese trade routes in the $16^{\text {th }}$ century (Roe, 1972). In South Africa, the plant has invaded croplands, forestry plantations, riparian and conservation areas, particularly in the higher rainfall regions of the country (Olckers, 1999). Although chemical control methods have proved effective in South Africa, biological control using herbivorous insects has been investigated as a more sustainable, long-term solution (Olckers, 2000; 2003).

Solanum mauritianum in its native country displays many ecological features that are typical of pioneer species. Some of these features include: (i) colonization of disturbed habitats that

\footnotetext{
* Author for correspondence: johpema@netpar.com.br
} 
are in the initial stages of ecological succession; (ii) the production of small, abundant seeds that are spread by birds and bats; (iii) germination under conditions of high temperature or light; and (iv) the ability of seeds to persist in a soil seed bank until conditions for their establishment are favorable (Denslow, 1980; Brokaw, 1985; Swaine and Whitmore, 1988). Due to these characteristics, the species is able to grow and to reproduce in human made habitats and this aggravates the biological invasion problem.

The structure of a plant population is determined by abiotic and biotic factors which influence the spatial arrangement, age group and genetic structure of the plants in the population (Hutchings, 1997). These factors also cause temporal and spatial changes in the number of plants within the population (Watkinson, 1997). Information on the population's regeneration ability (i.e., the recruitment of new plants relative to local mortality) or on the occurrence of prior disturbances can be obtained from assessments on the size distribution of plants in a population, if carefully interpreted (Harper, 1977). This kind of study has been carried out for some tropical plant species (Swaine et al., 1987, Marques and Joly, 2000), in which the size distribution has provided information on the local and point stability of the relevant population. Population structure also incorporates the spatial distribution of plants that, according to Janzen (1970), depends on their seed dispersal pattern and on the probability of seedling survival.

Herbivory can play a major role in determining the structure of a plant population and can vary according to the density and distance of the individuals from the parent plant (Janzen, 1970). In particular, leaf-feeding herbivorous insects often have a high reproductive capacity and can periodically reach high densities, causing defoliation, decreased plant growth and reproduction, and increased mortality (Hartley and Jones, 1997). Considering that plant reproductive success is dependent on a high production of leaves (Solbring, 1981) of good quality (Gramacho et al., 2001), sporadic or sustained instances of herbivory can significantly lower the regenerative capacity of plant populations (Howe, 1990; Doyle et al., 2002). Indeed, the exploitation of insect herbivores to lower the growth rates and reproductive capacity of invasive plants is the primary function of biological control. Several insect herbivore species have been identified as potential biological control agents for release against S. mauritianum in South Africa (Olckers, 1999; Pedrosa-Macedo et al., 2003). Besides several leaf-feeding insect species that have potential for reducing the plant's high growth rates, species that reduce flowering and fruiting have been given high priority (Olckers, 2003). In particular, flowerbud-feeding weevils of the genus Anthonomus (Curculionidae), which also feed on young leaves on the tips of the branches, have been studied on natural $S$. mauritianum populations around Curitiba in Brazil because of their abundance and importance as candidate agents.

Despite considerable information on the insect natural enemies associated with S. mauritianum in its native countries (Olckers et al., 2002; PedrosaMacedo et al., 2003), little is known about the auto-ecology of the target plant. Studies on the structure of S. mauritianum populations in its natural environment could help to elucidate the plant's population behavior and assess its susceptibility to attack by insect herbivores. The aim of this study was, thus, to describe the structure of a Solanum mauritianum population in an early successional area in the Metropolitan Area of Curitiba, Paraná, Brazil, and relate it with the degree of leaf damage. In particular, the following issues were addressed: (i) the size and spatial structure of the plant population; (ii) the amount of herbivory (in particular by Anthonomus species); and (iii) whether insect herbivory is related to plant size. On the basis of the above information, an attempt was made to define the stages in which the plants were more susceptible to insect attack as this could influence the selection of agents and proceedings for biological control.

\section{MATERIALS AND METHODS}

The study was carried out at the Centro de Estações Experimentais do Canguiri of Universidade Federal do Paraná, located in the county of Pinhais, Paraná State $\left(49^{\circ} 06^{\prime} 15^{\prime \prime} \mathrm{W}\right.$ and $25^{\circ} 24^{\prime} 30^{\prime \prime} \mathrm{S}, 1000 \mathrm{~m}$ altitude). The study area was previously used for agriculture and was abandoned approximately two years before the work started, thus being in the process of natural regeneration, with abundant pioneer species. The soil in the region is rarely deep (from 30 to $90 \mathrm{~cm}$ ) and has good drainage, an organic to clayey structure, 
typical of humic Cambisol and Xanthic Acric Ferralsol (Fupef, 2002) and has a soft relief that slopes slightly to the west. The study was carried out in the spring (September to November of 2003) when plants were flowering and fruiting.

A $3,200-\mathrm{m}^{2}$ area was subdivided into 32 adjacent $10 \times 10 \mathrm{~m}$ plots. All S. mauritianum plants that were more than $20 \mathrm{~cm}$ tall were marked and their height and diameter at soil level was recorded. This minimum height was selected because of the difficulty in distinguishing between smaller individuals of $S$. mauritianum and the related $S$. granuloso-leprosum. The data were analyzed to estimate the size structure of the population, based on the frequency distribution in the height and diameter classes. A Kolmogorov-Smirnov test was carried out to determine if size structure was different from homogenity (Zar, 1999). The spatial distribution of individual plants was evaluated by preparing maps of the density classes and using Morisita's index of dispersion (Brower and Zar, 1984), which determined whether the pattern was random $(\mathrm{MI}<1)$, aggregate $(\mathrm{MI}>1)$ or uniform $(\mathrm{MI}=1)$.

Leaf damage was assessed on each marked plant by sampling 30 leaves on three different branches (10 leaves per branch). For younger and smaller plants with less than three branches, 30 leaves from the existing branches were sampled. All leaves were sampled on plants with less than 30 leaves. Sampling started with the most basal leaf in each branch. Sampled leaves were recorded as: (i) whole (or undamaged); (ii) damaged solely by Anthonomus weevils; (iii) damaged by all other insects and (iv) damaged by Anthonomus weevils and all other insects. The damage caused by Anthonomus species was assessed because the weevils were frequent and had considerable potential as biological control agents (PedrosaMacedo et al., 2003). Feeding damage of the weevils was evidenced by small holes that were circular in the leaf lamina or semi-circular on the leaf borders, and leaf veins were all that remained after the intense feeding.

To estimate the leaf area lost by herbivory on the sampled branches, one leaf (the most basal) was collected for each of the four damage categories (see above). Branches that were not subject to all damage categories were sampled according to the categories represented. The leaves were taken to the laboratory for oven drying and measurement. The leaf area assessments were facilitated by Sigma Scan Pro 5.0 software, in which the leaves were glued to white A4 size paper and then scanned in black and white. Once the total area damaged by insects (i.e. the perforated area) was calculated, then all the leaf perforations were colored-in with felt-tipped pens and the leaves were scanned again to calculate to total leaf area. The differences between the second and first area measurements for each of the leaves were recorded as the percentage of the total leaf area lost to herbivory. The means and standard deviations of the leaf areas lost in each category were obtained from these data.

\section{RESULTS}

\section{Plant population structure}

A total of $222 S$ mauritianum plants was recorded in the study area (0.32 ha), indicating a population density of 694 plants.ha $^{-1}$. Plant heights ranged from 20 to $270 \mathrm{~cm}$ (mean=136.1 \pm 68.5$)$. The height class distribution (Fig.1a) was not uniform $(D=84.6 ; P<0.05)$, with a prevalence of individuals in classes 2 to 4 (from 45.5 to $121.5 \mathrm{~cm}$ ) and 7 to 8 (from 173 to $223.5 \mathrm{~cm}$ ). Individual stem diameters ranged from $0.32 \mathrm{~cm}$ to $9.23 \mathrm{~cm}$ $($ mean $=2.5 \pm 1.5)$. The diameter class distribution (Fig. 1b) was not uniform $(D=26.6 ; P<0.05)$ and showed a prevalence of individuals in classes 2, 3 and 4 (from 0.92 to $3.66 \mathrm{~cm}$ ), with a smaller number of individuals in classes 1, 5, 6 and 7. The distribution of individual plants in the population was not uniform (Fig. 2), showing groupings as confirmed by Morisita's Index (MI=2.09).

Insect herbivory: In addition to the damage caused by Anthonomus species, S. mauritianum leaves were damaged by leaf-cutting ants of the genus Acromyrmex (Hymenoptera: Formicidae), which caused semicircular cuts on the leaf borders. In addition, damage was caused by leaf-mining larvae of the flea beetle Acallepitrix sp. (Coleoptera: Chrysomelidae) and the moth Acrolepia sp. (Lepidoptera: Acrolepiidae) and by the leaf-sucking lace bugs Corythaica cyathicollis and Gargaphia decoris (Hemiptera: Tingidae) that caused chlorotic speckling of the leaves. 
a)

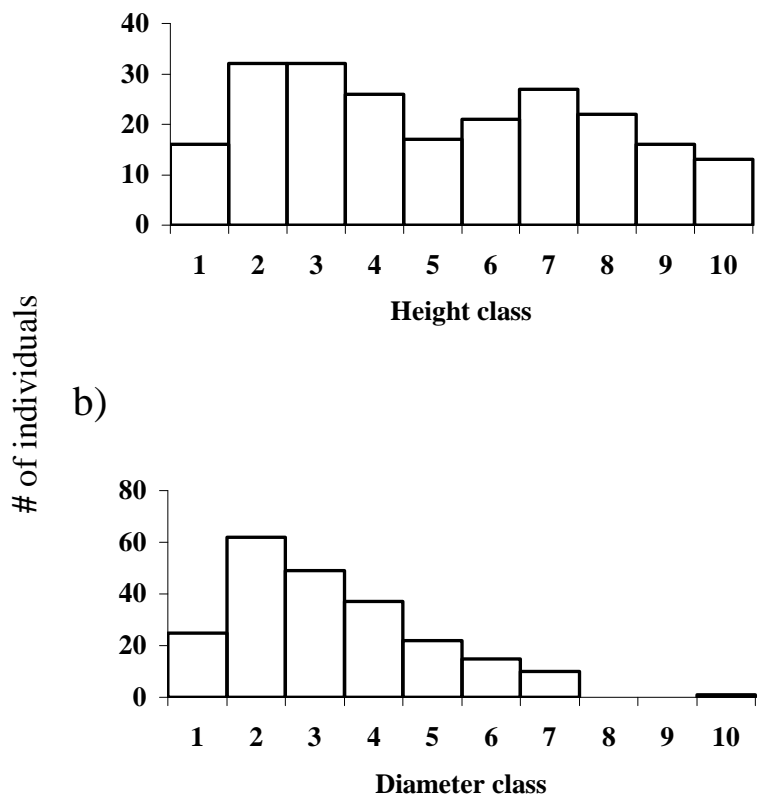

Figure 1 - The frequency of plant height class (a) and stem diameter class (b) within a Solanum mauritianum population in an area of regeneration in southern Brazil. Height classes (cm): $1=20<x \leq 45 ; 2=45<x \leq 70 ; 3=70<x \leq 95 ; 4=95<x \leq 120 ; 5=120<x \leq 145 ; 6=$ $145<x \leq 170 ; 7=170<x \leq 195 ; \quad 8=195<x \leq 220 ; 9=220<x \leq 245 ; 10=245<x \leq 270$. Diameter classes $(\mathrm{cm}): 1=0.001<\mathrm{x} \leq 0.923 ; 2=0.924<\mathrm{x} \leq 1.846 ; 3=1.847<\mathrm{x} \leq 2.769 ; 4=$ $2.770<x \leq 3.692 ; \quad 5=3.693<x \leq 4.615 ; \quad 6=4.616<x \leq 5.538 ; \quad 7=5.539<x \leq 6.461 ; \quad 8=$ $6.462<x \leq 7.384 ; 9=7.385<x \leq 8.307 ; 10=8.308<x \leq 9.230$.
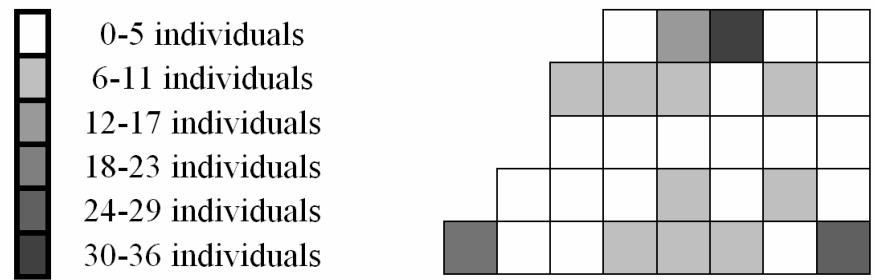

Figure 2 - Spatial distribution of Solanum mauritianum plants, according to six density classes, in 32 plots marked in an area of regeneration in southern Brazil.

The levels of herbivory were determined by an analysis of 5552 leaves. Of these, 5427 (97.8\%) were damaged by insects and only $125(2.2 \%)$ were intact. Of the damaged leaves, $81 \%$ were damaged by the other main insect groups (Acromyrmex spp., Acallepitrix sp., Acrolepia sp., Corythaica cyathicollis and Gargaphia decoris), while $14.5 \%$ were damaged by Anthonomus species and other insects, leaving only $2.3 \%$ (a low level) that were only damaged by Anthonomus species alone.

Looking at the relationship between the number of damaged leaves and plant height (Fig. 3), it appeared that the damage caused in two of the categories, notably by other insects and by other insects and Anthonomus spp., tended to increase with increased plant height $\left(r^{2}=0.36 ; F=56.23\right.$; $P<0.05$ and $r^{2}=0.03 ; F=6.61 ; P<0.05$, 
respectively). By contrast, the damage caused by Anthonomus spp. was not influenced by plant height $\left(r^{2}=0.0044 ; F=0.44 ; P=0.64\right)$.

The leaf area analysis indicated that leaves damaged by Anthonomus spp. were on average smaller than those attacked by other insects (Table 1), confirming observations that the weevils feed on younger leaves at the shoot tips. As expected, the leaf area lost due to damage caused by Anthonomus spp. was considerably less than that caused by the feeding of other insects (Table 1).

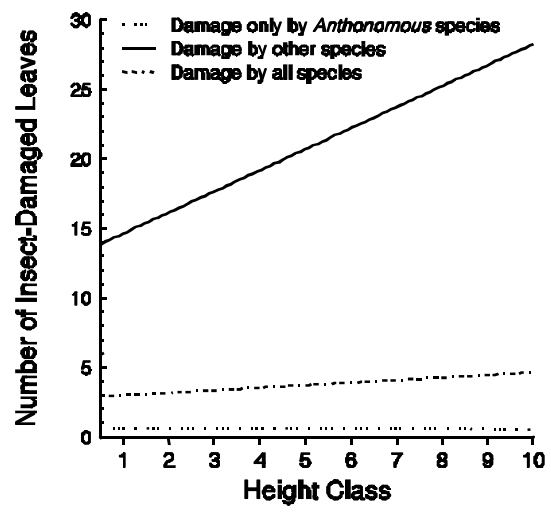

Figure 3 - Relationship between the number of insect-damaged leaves and plant height class (HC). Damage only by Anthonomus species $=13.933+1.7751 \mathrm{HC}-0.3174(\mathrm{HC}-0.909)^{2}$. Damage by all species $=3.39+0.2838$ HC-0.1710 $(\text { HC- } 4.909)^{2}$.

Table 1 - Mean ( \pm standard deviation) area of leaves of Solanum mauritianum that were subject to different categories of insect feeding and the leaf area that was lost as a result. Anthonomus spp. $N=198$; All other species $N=586$.

\begin{tabular}{ccc}
\hline Insect feeding & \multicolumn{2}{c}{ Leaf area $\left(\mathbf{c m}^{\mathbf{2}}\right)$} \\
\hline & Total & Lost by damage (\% of total) \\
\hline Anthonomus spp. & $20.34 \pm 12.17$ & $0.24 \pm 0.20(1.16 \%)$ \\
All other species & $67.38 \pm 37.38$ & $2.58 \pm 3.28(3.83 \%)$ \\
\hline
\end{tabular}

\section{DISCUSSION}

In the $S$. mauritianum population under study, the stem diameter class distribution showed an "inverted J" pattern that suggested population stability (Agreen and Zackrisson, 1990; Marques and Joly, 2000). However, the different pattern observed with the plant height classes suggested that the stems might have been disturbed in some moments in the past.

Although the $S$. mauritianum population was recently established (2 years old), this provided sufficient time for all size classes of individuals to be represented and suggested that the population was stable at that time. This rapid growth and establishment was typical of pioneer species
(Brokaw, 1987), such as S. mauritianum. The disparity between the stem diameter and plant height patterns could be ascribed to the mechanical clearing of individual plants, which sprouted and continued to grow (personal observation). As a result, stem diameter continued to increase normally, giving rise to the stable "inverted J" pattern, while plant height increments were disrupted by differential levels of cutting, affecting some older plants that were shorter than younger ones. The presence of a comparatively smaller number of individuals in diameter class I could have been influenced by the exclusion of plants smaller $20 \mathrm{~cm}$ from the sampling.

The S. mauritianum population displayed an aggregate spatial distribution pattern, as shown by 
the Morisita's indices. Studies on the structure and dynamics of plant populations have shown that the spatial distribution can be influenced by several biotic factors, including seed dispersal patterns and seedling survival, as well as abiotic factors like water and soil (Janzen, 1970; Hubbell, 1980; Marques and Joly, 2000). In S. mauritianum, the aggregate pattern might have been influenced by the aggregation of seeds under parental individual or by the vegetative propagation, since observations indicated several plants that were formed by vegetative "suckering". Though underground systems could be considered an additional problem to biological control (Kleinjan et al., 2004), plant aggregations might favor insect colonization and the subsequent build-up of large populations, because the plant populations provide an abundant and easily accessible food source.

The leaf-feeding insects recorded on S. mauritianum did not appear to display preferences based on the plants' developmental stage and attacked both young and adult plants. The high proportion of damaged leaves (98\%) also suggested that insects could contribute to the regulation of $\mathrm{S}$. mauritianum populations in native habitats, since the loss of photosynthetic area had been shown to reduce reproductive output by lowering the levels of flowering (Marquis, 1992b; Snow, 1994; Aizen and Raffaele, 1996) and seed production (Gramacho et al., 2001). Indeed, damage to leaves located in branches with flowers or flowerbuds was particularly destructive because these were the most important source of carbohydrates for the development of floral structures (Marquis, 1992a). Possibly the levels of herbivory on these leaves have a direct impact on the plant's reproductive capacity. Insects as Anthonomus spp. that attack floral tissues directly and also feed on younger leaves at the shoot tips, probably increase their impact on reproductive output.

The number of leaves damaged by Anthonomus spp. did not increase with increased plant height, despite the higher number of leaves available for feeding, confirming their preference for younger leaves at the shoot tips. By contrast, the number of leaves damaged by the other main insect herbivores increased with plant size, although this could be an effect of leaf damage that accumulated with time. Although the total leaf area that was estimated to have been lost by insect herbivory was low (around 5\% for all species), this probably was under-estimated to a large extent. This was because the evaluative method did not measure: (i) damage other than the leaf area that was missing at the time, (ii) reduced leaf vigour caused by leaf sucking and leaf mining, and, (iii) the levels of previous and future leaf abscission that would have resulted from high levels of feeding by the sap-sucking and leaf-mining insects. Indeed, the fact that only $2 \%$ of all leaves were not attacked by insects suggested that insect herbivory was much more significant than was suggested by the area loss table. Furthermore, this study did not consider the action of flower-feeding and stemboring species that were known to be abundant in the area (Pedrosa-Macedo et al., 2003) and which would further increased the levels of herbivory reported.

In conclusion, although the results have not shown a strong relation among $\mathrm{S}$. mauritianum population structure and insect herbivory, they suggested that leaf size and plant height was important for insect attack and must be considered to future biological control projects.

\section{ACKNOWLEDGEMENTS}

We thank to Agriculture Research Council - Plant Protection Research Institut (South Africa) for financial support, to Fundação de Pesquisas Florestais da Universidade Federal do Paraná (Brazil) for project administration and to Centro de Estações Experimentais do Canguiri of Universidade Federal do Paraná (Brazil) for field assistence. To João Renato Stemman for plant identification, to Maria Regina Torres Boeger for laboratory assistence and Augusta Karkow Doetzer for manuscript comments. We thank to Edgard Bredow, Luizimir Furmann, Thiago Granemann, Rafaela Sella and Lorena Stolle for field assistence.

\section{RESUMO}

Solanum mauritianum Scopoli (Solanaceae), um arbusto endêmico do sul do Brasil, naturalizou-se e tornou-se invasor em vários países do mundo. $\mathrm{Na}$ África do Sul, onde as invasões são severas, insetos fitófagos associados à planta no país de origem têm sido considerados para introdução como agentes de controle biológico. Para avaliar a ação de tais insetos no ambiente natural, foram conduzidos estudos em uma população de S. 
mauritianum em uma área em regeneração no sul do Brasil. Foi realizada análise da estrutura populacional, bem como da herbivoria causada por insetos, em particular para uma espécie do gênero Anthonomus (Curculionidae), para subsidiar o trabalho sobre controle biológico. A estrutura da população mostrou um padrão "J invertido" nas classes de diâmetro, mas não nas classes de altura; a distribuição espacial dos indivíduos era agregada. O dano causado por Anthonomus sp. não refletiu na perda real de grande área foliar. No entanto, uma vez que foi detectada uma grande freqüência de danos sobre indivíduos jovens, a herbivoria poderia levar à diminuição da sobrevivência da planta.

Palavras-chave: Estrutura populacional, Solanum, Anthonomus, hebivoria, controle biológico.

\section{REFERENCES}

Agreen, J, Zackrisson, O. (1990), Age and size structure of Pinus sylvestris on mires in central and northern Sweden. J. Ecol., 78, 1049-1062.

Aizen, M. A., Raffaele, E. (1996), Nectar production and pollination in Alstromeria aurea: responses to level and patern of flowering shoot defoliation. Oikos, 76, 312-322. 1996.

Brokaw, N. V. L. (1985), Treefall, regrowth, and community structure in tropical forests. In-The ecology of natural disturbance and patch dynamics. eds. S.T.A. Pickett, P.S. White. Academic Press, New York, pp. 53-69.

Brokaw, N. V. L (1987), Gap-phase regeneration of three pioneers tree species in a tropical forest. $J$. Ecol., 75, 9-19.

Brower, J. E., Zar, J. H (1984), Field and laboratory methods for field ecology. W.C. Brown Publishers, Boston.

Denslow J. S. G. (1980), Gap portioning among tropical rainforest trees. Biotropica, 12, 47-55.

Doyle, R. D., Grodowitz, M., Smart, R. M., Owens, C. (2002), Impact of herbivory by Hydrellia pakistanae (Diptera: Ephydridae) on growth and photosynthetic potential of Hydrilla verticillata. Biol. Control, 24, 221-229.

Fupef (2002), Siflor: Sistema de Informação para planejamento florestal. CD-Rom. Curitiba.

Gramacho, M., Santander, T., Farji-Brener, A. G (2001), Efectos de la herbivoría sobre la cantidad de ovulo en Loasa apeciosa (Loasaceae). Rev. Biol. Trop., 49, 513-516.

Harper, L. L. (1977), Population biology of plants. Academic Press, London.

Hartley, S. E., Jones, C. G. (1997), Plant chemistry and herbivory, or why the world is green. In-Plant
Ecology. ed. M. J. Crawley. Blackwell Science, Oxford, pp. 284-329

Howe, H. F. (1990), Survival and growth of juvenile Virola surinamensis in Panama: effects of herbivory and canopy closure. J. Trop. Ecol., 6, 259-280.

Hubbell, S. P. (1980), Seed predation and coexistence of tree species in tropical forest. Oikos, 35, 214-229.

Hutchings, M. J. (1997), The structure of plant populations. In-Plant Ecology. ed. M. J. Crawley. Blackwell Science, Oxford, pp.325-358.

Janzen, D. H. (1970), Herbivores and the number of tree species in tropical forests. Am. Nat., 104, 501528.

KissmanN, K. G., Groth, D. (1995), Plantas infestantes e nocivas. BASF S.A Editora. São Paulo.

Kleinjan, C. A., Edwards, P. B., Hoffman, J. H. (2004), Impact of foliage feeding by Zygina sp. on tuber biomass and reproduction of Asparagus asparagoides (L.): relevance to biological control in Australia. Biol. Control, 30, 36-41.

Marques, M. C. M., Joly, C. A. (2000), Estrutura e dinâmica de uma população de Calophyllum brasiliense Camb. em floresta higrófila do sudeste do Brasil. Rev. Bras. Bot., 23, 107-112.

Marquis, R. (1992a), A bite is a bite is a bite? Constrains on response to folivory in Piper arieianum (Piperaceae). Ecology, 73, 143-152.

Marquis, R. (1992b), The selective impact of herbivores. In-Plant resistance to herbivores and pathogenes: ecology evolutions and genetic. eds. R. Fretiz, E. Simms. Univ. Chicago Press, pp. 301-325.

Olckers, T. (1999), Biological control of Solanum mauritianum Scopoli (Solanacea) in South Africa: a review of candidate agents, progress and future prospects. Afr. Entomol., (Memoir No.1), 65-73.

Olckers, T. (2000), Biology, host specificity and risk assessment of Gargaphia decoris, the first agent to be released in South Africa for the biological control of the invasive tree Solanum mauritianum. Biocontrol, 45, 373-388.

Olckers, T., Medal, J. C., Gandolfo, D. E. (2002), Insects' herbivores associated with species of Solanum (Solanaceae) in northeastern Argentina and southeastern Paraguay, with reference to biological control of weeds in South Africa and the United States of America. Fla. Entomol., 85, 254-260.

Olckers, T. (2003), Assessing the risks associated with the release of a flowerbud weevil, Anthonomus santacruzi, against the invasive tree Solanum mauritianum in South Africa. Biol. Control, 28, 302312.

Pedrosa-Macedo, J. H., Olkers, T., Vitorino, M. D., Caxambu, M. G. (2003), Phytophagous arthropods associated with Solanum mauritianum Scopoli (Solanaceae) in the First Plateau of Paraná, Brazil: a cooperative project on biological control of weeds between Brazil and South Africa. Neotrop. Entomol., 32, 519-522. 
Roe, K. E. (1972), A revision of Solanum sect. Brevantherum (Solanaceae). Britonia, 24, 239-278.

Snow, A. (1994), Post-pollination selection and male fitness in plants. Am. Nat., 144, 69-83.

Solbring, O. T. (1981), Studies on the population biology of the genus Viola. II. The effect of plant size on fitness in Viola sororia. Evolution, 35, 1080-1093.

Swaine, M. D., Lieberman, D., Putz, F. E. (1987), The dynamics of tree populations in tropical forest: a review. J. Trop. Ecol., 3, 359-366.

Swaine, M. D., Whitmore, T. C. (1988), On the definition of ecological species groups in tropical rain forests. Vegetatio, 75, 81-86.
Watkinson, A. R. (1997), Plant population dynamics. In-Plant Ecology. ed. M. J. Crawley. Blackwell Science, Oxford, pp. 359-400.

Zar, J. A. (1999), Biostatistical analysis. Prentice-Hall, New Jersey.

Received: December 21, 2006; Revised: Setember 18, 2007; Accepted: December 20, 2008. 